\title{
PENGARUH KECERDASAN EMOSI TERHADAP PRODUKTIFITAS KERJA KARYAWAN PADA FUNGSI OPERASI DAN PENUNJANG PT. PERTAMINA (PERSERO) UNIT PENGOLAHAN BALONGAN INDRAMAYU
}

\author{
Zainal Mustafa Eq \\ Fakultas Ekonomi Universitas Islam Indonesia \\ Agus R \\ PT. Pertamina (Persero), Tbk, Balongan Indramayu
}

\begin{abstract}
This research was intended to investigate about the Working Productivities, especially of employees at the operational and supporting functions. The low working productivites at PT. Pertamina is caused by the low EQ of the Employees. Based on the research hypothesis, using descriptive analysis and inferential analysis, $F$ test dan $t$ test from the multiple linear regression and correlation, it was concluded that: a) The EQ of the employees was relatively low. b) The working productivity was also low. c) the effect of $E Q$ on the working productivity was indicated by $R 2=0.962$ with $F=535.204$ and significance level of 0.000. d) Based on the partial regression coefficient of the EQ dimension, the significance influence was found. Meanwhile social skill was the most (dominant) influential variable on the working productivity.
\end{abstract}

Keywords:Emotional Quotient and Working Productiviies.

\section{PENDAHULUAN}

Era global merubah segalanya menjadi cepat, hal ini menuntut organisasi untuk membuka diri terhadap beragam tuntutan perubahan, dan berupaya untuk menyusun strategi serta berbagai kebijakan yang sesuai dengan lingkungan baru, baik lingkungan eksternal maupun lingkungan internal.

Lingkungan eksternal lebih banyak melihat pada sisi luar organisasi yang meliputi munculnya ekspansi global, persaingan domestik dan skala internasional, perubahan karakteristik demografi, karakteristik angkatan kerja, kemajuan teknologi, otomatisasi dan sistem robotik. Sedangkan perubahan lingkungan internal lebih banyak melihat berbagai faktor yang berada di dalam organisasi yang meliputi nilai-nilai dan budaya, program pengembangan, struktur organisasional, pengendalian dan lain sebagainya.

Lebih lanjut adanya perubahan eksternal dan perubahan internal akan mempunyai implikasi positif bagi organisasi, salah satunya adalah meningkatnya keunggulan kompetitif yang dimiliki terutama potensi sumber daya manusia untuk memenangkan persaingan global.

Jadi strategi yang dilakukan oleh suatu organisasi didasarkan atas perubahan kondisi lingkungan secara terus menerus harus diupayakan dengan cara mengembangkan program-program yang mampu menerjemahkan dan mengakomodasi permasalahan-permasalahan terkini yang 
muncul. Salah satu bidang fungsional dalam organisasi yang strategis dan selalu menjadi perhatian adalah manajemen sumber daya manusia (MSDM).

Pemahaman peran sumber daya manusia secara tradisional akan berakibat akan dipakainya struktur organisasi sentralisasi dimana keterlibatan dari manajer lini sangat terbatas sehingga kemungkinan perencanaan dimulai dari atas ke bawah (top down). Kelemahan pada struktur ini tidak adanya komunikasi dua arah dan keterlibatan karyawan dalam proses perencanaan sangat terbatas.

Organisasi perlu secara terus menerus melakukan pengembangan sumber daya manusia, bagaimanapun divisi sumber daya manusia merupakan mitra divisi dalam upaya pengembangan kualitas sumber daya manusia. Paradigma baru sumber daya manusia sudah lebih mengoptimalkan pada proses komunikasi dua arah dan perencanaan dari bawah ke atas (bottom-up). Pada paradigma baru akan tercermin budaya kerja baru, strategi dan peran sumber daya manusia dari dalam tipologi organisasi baru.

Kecerdasan emosional seorang karyawan akan dapat menghantarkan mereka kepada produktivitas kerja yang tinggi. Hal ini diperkuat oleh hasil penelitian yang dilakukan Chipain yang dikutip oleh Savitri (2006: 1) dengan judul penelitian Emotional Intelligence and Its Relationship With Sales Success, yang hasilnya menyatakan bahwa kecerdasan emosional seorang karyawan akan berpengaruh pada kinerja.

PT. Pertamina (Persero) UP-VI Balongan Indramayu merupakan salah satu organisasi atau perusahaan milik negara yang bekerja dibidang perminyakan, dimana sampai saat ini melibatkan sebanyak 1.055 karyawan yang terdiri dari 833 orang $(78,5 \%)$ tenaga operasi dan sebanyak 222 orang $(21,0 \%)$ bagian penunjang operasi.
Meskipun tugas dari masingmasing karyawan sangat berbeda satu dengan yang lainnya, tapi saling bergantung, harus bekerja sama, dan juga harus saling mengisi demi tercapainya tujuan bersama, baik tujuan individu karyawan maupun tujuan kelompok atau organisasi. Untuk menunjang kemudahan pencapaian tujuan tersebut, karyawan baik secara individu maupun kelompok dituntut untuk terusmenerus melakukan perbaikan atau peningkatan kualitas dirinya atau kelompoknya.

Melakukan pekerjaan dalam suatu organisasi yang diatur oleh berbagai peraturan atau pedoman kerja, disiplin tertentu dan standar kerja atau target tertentu tidak saja memerlukan tingkat kemampuan intelektual (IQ) tetapi juga kemampuankemampuan lain yang sangat berperan, yaitu kecerdasan emosional (EQ).

Meskipun Pertamina UP-VI Balongan telah berupaya melakukan peningkatan produktivitas kerja karyawannya dengan berbagai cara, namun sampai saat ini masih dirasa belum dapat mencapai pada tingkatan yang diinginkan. Berbagai fasilitas pendukung dapat dikatakan telah cukup memadai untuk melakukan kerja secara efisien.

Ancaman kompetisi internasional, dan kondisi perekonomian yang tidak menentu serta perubahan teknologi yang begitu cepat merupakan beberapa faktor eksternal yang menyebabkan pimpinan organisasi mencari berbagai macam cara untuk dapat memberdayakan sumber daya manusia secara lebih efektif.

Secara umum penilaian produktivitas kerja telah banyak dilakukan oleh perusahaan-perusahaan, karena penilaian produktivitas kerja mempunyai manfaat yang sangat banyak bagi kebijakan manajemen dalam kaitannya dengan sumber daya manusia. Sedangkan tingginya tingkat produktivitas tersebut dapat ditingkatkan melalui peningkatan kecerdasan emosional, 
karena pada dasarnya kecerdasan emosional seorang karyawan dapat dipelajari dan dapat dapat dilatih.

Berdasarkan uraian diatas maka penelitian ini bertujuan untuk mengetahui seberapa besar pengaruh kecerdasan emosi terhadap produktifitas kerja karyawan pada fungsi operasi adn penunjang PT. Pertamina (Persero) Unit pengolahan Balongan Indramayu.

\section{LANDASAN TEORI}

\section{Manajemen Sumber Daya Manusia}

Organisasi sebagai suatu sistem, terdiri dari orang-orang yang saling mempunyai ketergantungan, bekerja sama dengan arah dan tujuan yang sama, baik untuk mencapai tujuan bersama maupun tujuan pribadi. Organisasi akan dapat menjalankan fungsinya jika di dalamnya ada pengelolaan (manajemen) yang baik, sehingga manajemen dan organisasi merupakan dua pengertian yang tidak dapat dipisahkan.

Manajemen sumber daya manusia (MSDM) bukanlah sesuatu yang baru di lingkungan organisasi, khususnya dibidang bisnis yang disebut dengan perusahaan. Organisasi yang terdiri dari orang-orang yang secara sengaja melakukan kerja sama untuk mencapai tujuan, secara terusmenerus melakukan upaya untuk mendapatkan yang terbaik sebagai hasil kerjanya. Upaya-upaya manusia tersebut bukan sesuatu yang bersifat statis, tetapi terus berkembang dan berubah seirama dengan dinamika perubahan kehidupan manusia.

Dari uraian di atas, jelaslah bahwa terbentuknya suatu organisasi didasari sepenuhnya oleh hakekat kemanusiaannya. Melalui kelembagaan atau suatu organisasi, yang dapat dibentuk dalam institusi tersebut, organisasi dan para anggotanya dapat menjalankan hidup dan kehidupan manusia yang baik. Jadi sumber daya manusia merupakan aktivitas yang sangat penting dalam suatu organisasi. Titik fokusnya adalah orang-orang, karena orang-orang merupakan darah dari suatu organisasi Manajemen sumber daya manusia yang efektif mengharuskan manajer menemukan cara terbaik dalam mengkaryakan orang orang agar tujuan organisasi dapat tercapai dan peningkatan organisasi serta pencapaian tujuan-tujuan pribadi anggota organisasi. Para manajer harus mampu menemukan berbagai metode untuk dapat meningkatkan kepuasan karyawan, komitmennya, keterlibatannya dalam gerak operasi organisasi dan memperbaiki kualitas lingkungan kerja.

Manajer sumber daya manusia ataupun suatu departemen yang mengurus sumber daya manusia pada suatu organisasi, dalam suatu masyarakat akan terpenuhi harapannya apabila mampu mencapai tujuan manajemen sumber daya manusia tersebut secara tepat, baik dan benar. Seringkali kegagalan dalam mengelola suatu sumber daya manusia dapat mengakibatkan timbulnya gangguan dalam pencapaian-pencapaian tujuan organisasi, baik terhadap "performance"-nya, "profit"-nya maupun kelangsungan hidup organisasi itu sendiri. inilah suatu tantangan yang harus dihadapi oleh suatu departemen "human resource management" atau setiap manajer sumber daya manusia.

\section{Kecerdasan Emosi}

Kecerdasan emosi mencakup kemampuan-kemampuan yang berbeda, tetapi saling melengkapi dengan kecerdasan akademik, yaitu kemampuan-kemampuan kognitif murni yang diukur dengan IQ. Banyak orang yang cerdas (dalam arti terpelajar) tetapi mereka tidak mempunyai kecerdasan emosi. Kedua kecerdasan yang berbeda ini (intelektual dan emosi) mengungkapkan aktivitas bagian-bagian yang berbeda dalam otak. 
Teori sistem menyatakan bahwa mengabaikan kategori data apapun yang signifikan identik dengan membatasi pemahaman dan respon seseorang. Memahami arus emosi dalam perusahaan dapat mendatangkan manfaat yang nyata. Kerugian dapat dialami oleh suatu perusahaan ketika manajer selalu mengabaikan emosi karyawan yang bekerja.

Emosi yang dimiliki oleh seseorang sebenarnya berisi seluruh kejadian atau pengalaman yang pernah dialaminya. Manusia sebagai sistem, kekuatan emosinya ditunjukkan dalam bentuk energi dan inilah sumber utama pengaruh dan kekuatan manusia dalam mengarungi kehidupannya. Emosi yang berlebihan pada suatu waktu dapat menghambat atau menghentikan penalaran dan analisis yang bersifat rasional, tetapi kejadian pada sebagian kasus menjelaskan bahwa emosi yang terlalu rendah justru dapat menghancurkan karir dan sekaligus perusahaan.

Kecerdasan emosi (EQ) merujuk kepada kemampuan mengenali perasaan diri sendiri dan perasaan orang lain, kemampuan memotivasi diri sendiri dan kemampuan mengelola emosi dengan baik pada diri sendiri dan dalam hubungannya dengan orang lain (Goleman, 2005:512).

Salovey dan Mayer dalam Goleman (2005:513) mendefinisikan "kecerdasan emosi sebagai kemampuan memantau dan mengendalikan perasaan sendiri dan orang lain, serta menggunakan perasaan-perasaan itu untuk memandu pikiran dan tindakan".

Tentu saja tidak cukup hanya memiliki perasaan, kecerdasan emosional menuntut seseorang untuk belajar mengakui dan menghargai perasaan, pada diri sendiri dan orang lain, dan untuk menanggapi (merespon) dengan tepat, menerapkan dengan efektif informasi dan energi emosi dalam kehidupan dan pekerjaan sehari-hari.

\section{Produktivitas Kerja}

Produktivitas kerja pada hakekatnya adalah suatu sikap mental yang selalu berusaha dan berpandangan bahwa mutu kehidupan hari ini harus lebih baik dari hari kemarin, dan mutu kehidupan hari esok harus lebih dari hari ini. Pengertian ini mendorong seorang karyawan untuk selalu kreatif mencari metode untuk meningkatkan taraf hidup diwaktu-waktu mendatang.

Produktivitas kerja mengandung pengertian perbandingan antara hasil yang dapat dicapai dengan peran tenaga kerja yang bersangkutan per satuan waktu. Secara matematis, jika hasil kerja atau output $=\mathrm{O}$ dan peran tenaga kerja atau input $=\mathrm{I}$, maka produktivitas kerja $=(\mathrm{O} / \mathrm{I})^{*} 100 \%$. Seorang tenaga kerja dinilai produktif jika yang bersangkutan mampu menghasilkan output lebih banyak dalam satuan waktu tertentu. Jika produktivitas kerja hanya dikaitkan dengan waktu saja, maka jelas kiranya bahwa produktivitas kerja sangat tergantung pada segi ketrampilan dan keahlian tenaga kerja secara fisik.

Mangkunegara (2000:67) mendefinisikan produktivitas kerja sebagai hasil kerja secara kualitas dan kuantitas yang dicapai oleh seorang pegawai dalam melaksanakan tugasnya sesuai dengan tanggung jawab yang diberikan kepadanya.

Penilaian produktivitas kerja pada dasarnya merupakan salah satu faktor kunci guna mengembangkan suatu organisasi secara efektif dan efisien. Perusahaan yang telah melakukan penilaian produktivitas kerja, berarti suatu organisasi telah memanfaatkan secara baik atas sumber daya manusia yang dalam perusahaan. Untuk keperluan penilaian produktivitas kerja tersebut, diperlukan informasi informasi yang relevan (valid) dan reliabel. Meskipun informasi yang digunakan untuk penilaian mempunyai tingkat kualitas yang tinggi, namun permasalahannya adalah bagaimana suatu penilaian akan menjamin adanya 
"obyektivitas". Hal ini harus dipikirkan dan diperhatikan dalam proses penilaian produktivitas kerja karyawan, artinya harus dihindarkan dari adanya sifat "suka" dan 'tidak suka" dari penilai.

\section{Kerangka Pikir}

Kecerdasan emosi yang setelah melalui berbagai telaah akan diukur melalui lima dimensi yang meliputi: kesadaran diri, pengaturan diri, motivasi, empati dan ketrampilan sosial, baik secara simultan (bersama-sama) maupun secara parsial dapat mempengaruhi tingkat produktivitas kerja. Secara visual bentuk atau model pengaruh tersebut dapat digambarkan ke dalam sebuah bagan sebagaimana tampak pada Gambar 1 .
Hipotesis

Berdasarkan kerangka pikir dalam penelitian ini dan berdasarkan rumusan masalah, maka dapat disusun hipotesis sebagai berikut:

1. Secara simultan (serentak) variabelvariabel dalam kecerdasan emosi mempunyai pengaruh yang positif dan signifikan terhadap produktivitas kerja karyawan.

2. Secara parsial (individual) variabelvariabel dalam kecerdasan emosi mempunyai pengaruh yang signifikan terhadap produktivitas kerja karyawan.

3. Salah satu variabel dalam kecerdasan emosi ada yang dominan pengaruhnya terhadap produktivitas kerja karyawan.

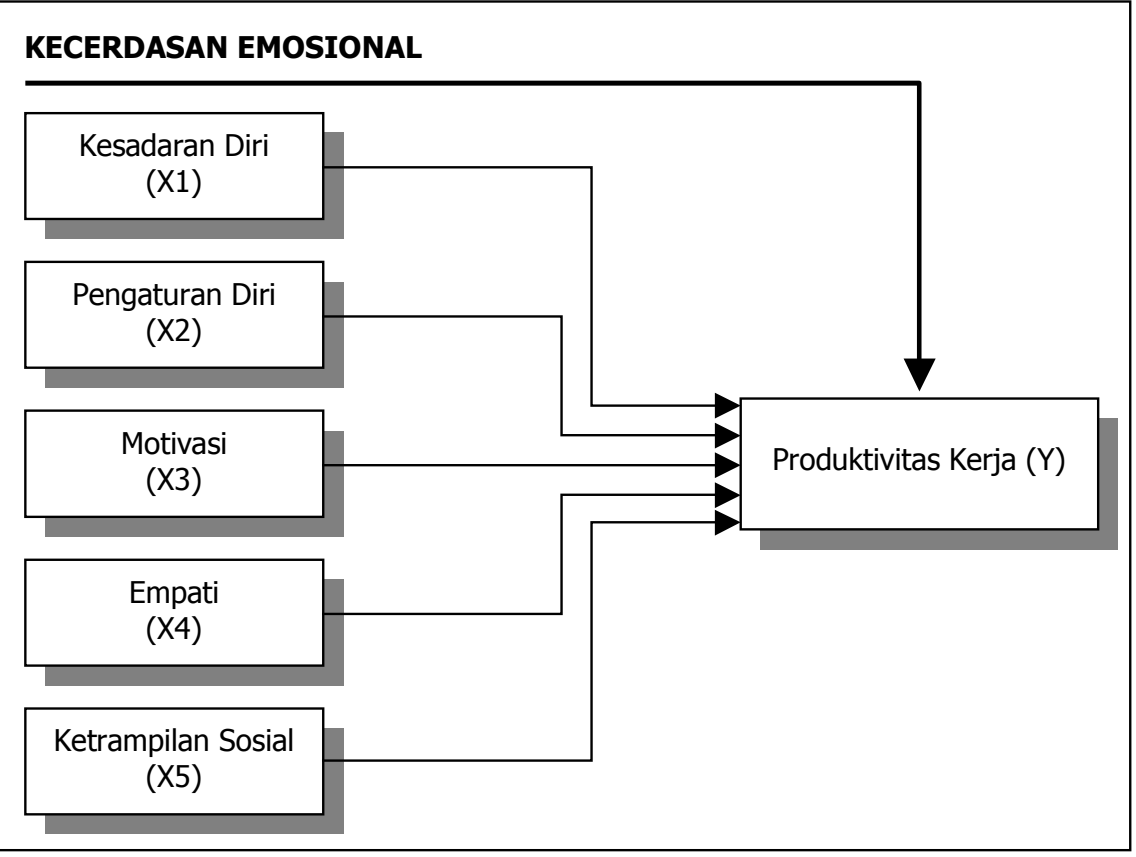

Gambar 1: Kerangka Pikir Penelitian 


\section{METODE PENELITIAN \\ Populasi dan Sample Penelitian}

Mengingat jumlah karyawan yang

sangat banyak mencapai 1.115 karyawan, maka metode sampling dianggap tepat dalam melakukan penelitian di PT. Pertamina (Persero) unit Pengolahan VI Balongan Indaramayu. Nazir (1985:325) mendefinisikan sampel sebagai bagian dari populasi. Sedangkan "survei sampel" adalah suatu prosedur dan hanya sebagian dari populasi saja yang diambil dan dipergunakan untuk menentukan sifat serta ciri yang dikehendaki dari populasi.

\section{Teknik Pengumpulan Data}

Data dikumpulkan melalui penyebaran kuesioner, yang diberikan secara langsung dengan menjelaskan terlebih dahulu maksud dan tujuan penelitian untuk kepentingan ilmiah, kemudian menjelaskan bagaimana cara pengisian kuesioner yang telah dibuat dengan sangat sederhana dan sangat mudah untuk dapat dipahami. Adapun angket yang digunakan yaitu adaptasi dari rasa keberagaman tingkat emosional karyawan. Selain mencari data primer peneliti juga mencari data sekunder.

\section{Metode Analisis Data \\ Uji Deskripsitif}

Analisis deskriptif adalah analisis data yang dimaksudkan untuk memberikan uraian-uraian dari data yang telah ditabulasikan dalam bentuk tabel distribusi frekuensi, dan tidak dimaksudkan untuk melakukan pengujian-pengujian statistik. Dengan mendeskripsikan data hasil penelitian tersebut, maka data akan bermakna untuk menjelaskan karakteristik responden dan performa setiap variabel yang diukur dalam penelitian ini.

\section{Uji Validitas}

Uji validitas dimaksudkan untuk menguji apakah data hasil penelitian benar- benar merupakan ukuran yang seharusnya bagi variabel-variabel penelitian. Pengujian terhadap tingkat validitas data akan dilakukan dengan menggunakan formula korelasi product moment dari Pearson antara skor setiap item dengan skor total dari itemitem tersebut.

\section{Uji Reliabilitas}

Pengujian reliabilitas adalah untuk mengetahui apakah data-data tersebut mempunyai derajat konsistensi yang tinggi. Pengujian reliabilitas menggunakan formula dari Alpha Cronbach yang telah distandardisasikan.

\section{Uji Hipotesis}

Alat analisis yang akan digunakan untuk menguji hipotesis adalah "analisis regresi dan korelasi linier ganda (multyple regression and correlarional)", serta analisis korelasi parsial, sedangkan untuk memudahkan dalam proses perhitungannya akan digunakan program paket "SPSS". Langkah-langkah yang diperlukan dalam analisis ini meliputi:

1. Uji Hipotesis Regresi Linier Ganda sebagai berikut:

$$
\begin{aligned}
\mathrm{Y}= & { }_{0}+\beta_{1} \mathrm{X} 1+\beta_{2} \mathrm{X} 2+\beta_{3} \mathrm{X} 3+\beta_{4} \mathrm{X} 4 \\
& +\beta_{5} \mathrm{X} 5+\beta_{1}
\end{aligned}
$$

dimana:

X1 : Total skor variabel X1 (kesadaran diri)

X2 : Total skor variabel X2 (pengaturan diri)

$\mathrm{X} 3$ : Total skor variabel X3 (motivasi)

X4 : Total skor variabel X4 (empati)

X5 : Total skor variabel X5 (ketrampilan sosial)

i : Koefisien regresi.

$\varepsilon \quad:$ Error dalam model

2. Menghitung harga koefisien Determinasi Ganda $\left(\mathrm{R}^{2}\right)$ :

$$
R^{2}=\frac{\text { Jumlah Kuadrat Regresi }}{\text { Jumlah Kuadrat Total }}
$$


Harga koefisien Determinasi Ganda akan berkisar antara 0 hingga 1 . Semakin mendekati angka 1, maka pengaruh atau hubungan tersebut dikatakan semakin kuat.

3. Menguji Pengaruh Simultan.

Menguji pengaruh simultan adalah menguji pengaruh dari seluruh variabel bebas secara bersama-sama terhadap variabel terikat. Hipotesis kerja sebagai berikut:

$\mathbf{H}_{\mathbf{0}}: \rho=0$ atau $\beta_{1}=\beta_{2}=\beta_{3}=\beta_{4}=\beta_{5}=0$ (secara bersama-sama semua variabel bebas tidak berrpengaruh terhadap variabel terikat)

$\mathbf{H}_{1}$ : $\quad \neq 0$ atau secara serentak semua variabel variabel bebas berpengaruh terhadap variabel terikat.

Jika pengujian mengasilkan harga taraf signifikansi dari uji $\mathrm{F}$ sebesar $\leq 0,05$, maka $\mathrm{H}_{0}$ ditolak, artinya ada pengaruh yang signifikan antara variabel bebas secara bersama-sama terhadap variabel terikat.

4. Mencari harga koefisien korelasi parsial.

Koefisien korelasi parsial dapat dihitung dari koefisien korelasi antara satu variabel bebas dengan variabel terikat jika variabel bebas yang lain dikontrol. Harga ini akan identik dengan harga koefisien regresi dari skor-skor variabel yang telah distandardisasikan (dikonversi dalam nilai Z).

5. Menguji Koefisien Korelasi Parsial.

Harga koefisien korelasi parsial akan diuji dengan menggunakan uji t. dengan hipotesis kerja sebagai berikut:

$\mathbf{H}_{\mathbf{0}}: \mathrm{i}_{\mathrm{i}}=0$ atau $\mathrm{Z} \beta_{\mathrm{i}}=0$

$\mathbf{H}_{\mathbf{1}}: \rho_{\mathrm{i}} \neq 0$ atau $Z \beta_{\mathrm{i}} \neq 0$

Jika dari uji $\mathrm{t}$ menghasilkan taraf signifikansi sebesar $\leq 0,05$, maka $\mathrm{H}_{0}$ ditolak, artinya ada pengaruh yang signifikan antara variabel satu bebas tertentu secara parsial terhadap variabel terikat. Diantara beberapa koefisien korelasi parsial yang dinyatakan signifikan dan mempunyai harga terbesar, maka variabel bebas tersebut dinyatakan sebagai variabel yang paling kuat (dominan) pengaruhnya terhadap variabel terikat.

6. Melakukan pengujian terhadap asumsi klasik.

Beberapa asumsi klasik yang mendasari digunakannya analisis regresi linier diantaranya adalah:

a. Normalitas data.

b. Pengujian normalitas data dapat digunakan pendekatan tendensi sentral, yaitu dengan mencari harga-harga Mean, Median dan Modus. Jika ketiga harga tersebut relatif sama, maka data dapat dinyatakan berdistribusi normal.

c. Lineritas.

d. Pengujian dilakukan ploting model.

e. Heteroskedastisitas.

f. Pengujian terhadap sifat heteroskedastisitas dilakukan dengan menggunakan pendekatan korelasi Rank Spearman. Jika uji t dari koefisien korelasi Rank Spearman menghasilkan taraf signifikansi $\leq$ 0,05 maka dapat dinyatakan tidak ada sifat heteroskedastisitas.

g. Multokolinearitas.

h. Dalam penggunaan alat analisis regresi ganda linier, maka diasumsikan bahwa tidak akan terjadi pengaruh antara satu variabel bebas dengan variabel bebas lainnya. Jika hal itu terjadi, maka sebenarnya model regresi ganda dapat lebih disederhanakan modelnya. Namun demikian pada suatu penelitian yang tidak ingin menyederhanakan model, maka kasus terjadinya multikolinearitas dapat diabaikan. 
Definisi Operasional Variabel Penelitian Mengenai indikator masing-masing variabel sebagai berikut:

1. Pengaruh kecendrungan emosi yang ada pada diri karyawan meliputi; Kesadaran diri, Pengaturan diri, Motivasi, Empati, dan Ketrampilan sosial karyawan dalam melaksanakan pekerjaan.

2. Produktivitas kerja merupakan kemampuan seorang karyawan dalam melakukan pekerjaannya dengan prosedur yang disarankan atau diatur oleh perusahaan untuk menghasilkan barang atau jasa sesuai dengan standar kualitas dan kuantitas tertentu.

\section{HASIL PENELITIAN}

\section{Hasil Penyebaran Kuesioner}

Untuk mendapatkan data sebanyak 111 unit, peneliti telah mengedarkan angket lebih dari 120 eksemplar. Dalam perjalanannya ada responden yang tidak mengembalikan angket. Maka responden diganti dengan menggunakan sistem acak, hingga diperoleh data sesuai dengan yang direncanakan sebanyak 120 angket terisi.

\section{Uji Validitas dan Reliabilitas}

Untuk menjamin bahwa data yang dikumpulkan tersebut mempunyai tingkat validitas dan reliabilitas yang dapat diterima, maka perlu dilakukan pengujian terhadap validitas dan reliabilitasnya. Masing-masing perhitungan dilakukan sebagai berikut:

\section{Uji Validitas \\ Uji Validitas Faktor Kesadaran Diri}

Variabel kesadaran diri diukur dengan menggunakan empat indikator, di mana nilai dari variabel kesadaran diri adalah total dari skor-skor setiap indikatornya. Jika hasil pengolahan data menunjukkan taraf signifikansi kurang dari 0,05, maka dapat disimpulkan bahwa butir atau data yang diuji adalah valid. Secara keseluruhan hasil uji validitas untuk instrumen pengukur kesadaran diri dapat dilihat pada Tabel 1.

\section{Uji Validitas Faktor Pengaturan Diri}

Variabel pengaturan diri diukur dengan menggunakan enam indikator, di mana nilai dari variabel pengaturan diri adalah total dari skor-skor setiap indikatornya. Jika hasil pengolahan data menunjukkan taraf signifikansi kurang dari 0,05, maka dapat disimpulkan bahwa butir atau data yang diuji adalah valid. Secara keseluruhan hasil uji validitas untuk instrumen pengukur pengaturan diri dapat dilihat pada Tabel 2 .

Tabel 1: Hasil Uji Validitas Untuk Variabel Kesadaran Diri

\begin{tabular}{|c|c|c|c|c|}
\hline Variabel & Butir & Koef. Korr. Pearson & Sig. & Keterangan \\
\hline \multirow{3}{*}{$\begin{array}{c}\text { Kesadaran Diri } \\
\text { (X1) }\end{array}$} & $\mathrm{x} 11$ & 0,763 & 0,000 & Valid \\
\cline { 2 - 5 } & $\mathrm{x} 12$ & 0,846 & 0,000 & Valid \\
\cline { 2 - 5 } & $\mathrm{x} 13$ & 0,829 & 0,000 & Valid \\
\cline { 2 - 5 } & $\mathrm{x} 14$ & 0,816 & 0,000 & Valid \\
\hline
\end{tabular}

Sumber: data primer diolah. 
Tabel 2: Hasil Uji Validitas Untuk Variabel Pengaturan Diri

\begin{tabular}{|c|c|c|c|c|}
\hline Variabel & Butir & Koef. Korr. Pearson & Sig. & Keterangan \\
\hline \multirow{4}{*}{$\begin{array}{c}\text { Pengaturan Diri } \\
\text { (X2) }\end{array}$} & $\mathrm{x} 21$ & 0,796 & 0,000 & Valid \\
\cline { 2 - 5 } & $\mathrm{x} 22$ & 0,857 & 0,000 & Valid \\
\cline { 2 - 5 } & $\mathrm{x} 23$ & 0,873 & 0,000 & Valid \\
\cline { 2 - 5 } & $\mathrm{x} 24$ & 0,901 & 0,000 & Valid \\
\cline { 2 - 5 } & $\mathrm{x} 25$ & 0,889 & 0,000 & Valid \\
\cline { 2 - 5 } & $\mathrm{x} 26$ & 0,790 & 0,000 & Valid \\
\hline
\end{tabular}

Sumber: data primer diolah.

Tabel 3: Hasil Uji Validitas Untuk Variabel Motivasi

\begin{tabular}{|c|c|c|c|c|}
\hline Variabel & Butir & Koef. Korr. Pearson & Sig. & Keterangan \\
\hline \multirow{4}{*}{ Motivasi (X3) } & X31 & 0,890 & 0,000 & Valid \\
\cline { 2 - 5 } & $\mathrm{x} 32$ & 0,845 & 0,000 & Valid \\
\cline { 2 - 5 } & $\mathrm{x} 33$ & 0,876 & 0,000 & Valid \\
\cline { 2 - 5 } & $\mathrm{x} 34$ & 0,877 & 0,000 & Valid \\
\cline { 2 - 5 } & $\mathrm{x} 35$ & 0,859 & 0,000 & Valid \\
\hline
\end{tabular}

Sumber: data primer diolah.

\section{Uji Validitas Faktor Motivasi}

Variabel motivasi diukur dengan menggunakan lima indikator, dimana nilai dari variabel motivasi adalah total dari skorskor setiap indikatornya. Jika hasil pengolahan data menunjukkan taraf signifikansi kurang dari 0,05 , maka dapat disimpulkan bahwa butir atau data yang diuji adalah valid. Secara keseluruhan hasil uji validitas untuk instrumen pengukur tingkat motivasi kerja dapat dilihat pada Tabel 3 di atas.

\section{Uji Validitas Faktor Empati Karyawan}

Variabel empati diukur dengan menggunakan lima indikator, dimana nilai dari variabel empati adalah total dari skorskor setiap indikatornya. Jika hasil pengolahan data menunjukkan taraf signifikansi kurang dari 0,05, maka dapat disimpulkan bahwa butir atau data yang diuji adalah valid. Secara keseluruhan hasil uji validitas untuk instrumen pengukur tingkat empati (sebagai dimensi kecerdasan emosi) terhadap pekerjaannya dapat dilihat pada Tabel 4.

Tabel 4: Hasil Uji Validitas Untuk Variabel Empati

\begin{tabular}{|c|c|c|c|c|}
\hline Variabel & Butir & Koef. Korr. Pearson & Sig. & Keterangan \\
\hline \multirow{4}{*}{ Empati (X4) } & $\mathrm{x} 41$ & 0,844 & 0,000 & Valid \\
\cline { 2 - 5 } & $\mathrm{x} 42$ & 0,874 & 0,000 & Valid \\
\cline { 2 - 5 } & $\mathrm{x} 43$ & 0,855 & 0,000 & Valid \\
\cline { 2 - 5 } & $\mathrm{x} 44$ & 0,825 & 0,000 & Valid \\
\cline { 2 - 5 } & $\mathrm{x} 45$ & 0,793 & 0,000 & Valid \\
\hline
\end{tabular}

Sumber: data primer diolah. 
Tabel 5: Hasil Uji Validitas Untuk Variabel Ketrampilan Sosial

\begin{tabular}{|c|c|c|c|c|}
\hline Variabel & Butir & Koef. Korr. Pearson & Sig. & Keterangan \\
\hline \multirow{4}{*}{$\begin{array}{c}\text { Ketrampilan } \\
\text { Sosial (X5) }\end{array}$} & $\mathrm{x} 51$ & 0,839 & 0,000 & Valid \\
\cline { 2 - 5 } & $\mathrm{x} 52$ & 0,860 & 0,000 & Valid \\
\cline { 2 - 5 } & $\mathrm{x} 53$ & 0,845 & 0,000 & Valid \\
\cline { 2 - 5 } & $\mathrm{x} 54$ & 0,825 & 0,000 & Valid \\
\cline { 2 - 5 } & $\mathrm{x} 55$ & 0,840 & 0,000 & Valid \\
\hline
\end{tabular}

Sumber: data primer diolah.

Tabel 6: Hasil Uji Validitas Untuk Variabel Produktivitas Kerja

\begin{tabular}{|c|c|c|c|c|}
\hline Variabel & Butir & Koef. Korr. Pearson & Sig. & Keterangan \\
\hline \multirow{4}{*}{$\begin{array}{c}\text { Produktivitas } \\
\text { Kerja (Y) }\end{array}$} & $\mathrm{y} 1$ & 0,820 & 0,000 & Valid \\
\cline { 2 - 5 } & $\mathrm{y} 2$ & 0,768 & 0,000 & Valid \\
\cline { 2 - 5 } & $\mathrm{y} 3$ & 0,727 & 0,000 & Valid \\
\cline { 2 - 5 } & $\mathrm{y} 4$ & 0,768 & 0,000 & Valid \\
\cline { 2 - 5 } & $\mathrm{y} 5$ & 0,771 & 0,000 & Valid \\
\cline { 2 - 5 } & $\mathrm{y} 6$ & 0,739 & 0,000 & Valid \\
\hline
\end{tabular}

Sumber: data primer diolah.

\section{Uji Validitas Faktor Ketrampilan Sosial}

Variabel ketrampilan sosial diukur dengan menggunakan lima indikator, dimana nilai dari variabel ketrampilan sosial adalah total dari skor-skor setiap indikatornya. Jika hasil pengolahan data menunjukkan taraf signifikansi kurang dari 0,05, maka dapat disimpulkan bahwa butir atau data yang diuji adalah valid. Secara keseluruhan hasil uji validitas untuk instrumen pengukur tingkat ketrampilan sosial dapat dilihat pada Tabel 5 di atas.

\section{Uji Validitas Faktor Produktivitas Kerja}

Variabel produktivitas kerja diukur dengan menggunakan enam indikator, dimana nilai dari variabel produktivitas kerja adalah total dari skor-skor setiap indikatornya. Jika hasil pengolahan data menunjukkan taraf signifikansi kurang dari 0,05, maka dapat disimpulkan bahwa butir atau data yang diuji adalah valid. Secara keseluruhan hasil uji validitas untuk instrumen pengukur tingkat produktivitas keja dapat dilihat pada Tabel 6 di atas.

\section{Uji Reliabilitas}

Reliabilitas dalam penelitian dengan menggunakan menggunakan rumus indek alpha dari Cronbach. Dengan ketentuan apabila nilai Cronbach Alpa $>0.6$ maka instrumen pengukuran reliabel (Sekaran, 2000). Hasil dari masing-masing variabel seluruh item pernyataan adalah reliabel. Hasil pengujian tersebut selengkapnya dapat dilihat pada Lampiran 3 dan ringkasannya dapat diikuti pada Tabel 7 berikut. 
Tabel 7: Hasil Pengujian Reliabilitas Angket

\begin{tabular}{|l|c|c|}
\hline \multicolumn{1}{|c|}{ Variabel } & $\begin{array}{c}\text { Standardized Item } \\
\text { Alpha }\end{array}$ & Keterangan \\
\hline Kesadaran Diri (X1) & 0,8298 & Reliabel \\
\hline Pengaturan Diri (X2) & 0,9237 & Reliabel \\
\hline Motivasi (X3) & 0,9193 & Reliabel \\
\hline Empati (X4) & 0,8942 & Reliabel \\
\hline Ketrampilan Sosial (X5 & 0,8971 & Reliabel \\
\hline Produktivitas Kerja (Y) & 0,8587 & Reliabel \\
\hline
\end{tabular}

Sumber: Data primer yang diolah

Hasil Uji Hipotesis Pengaruh Serentak

Hasil uji serentak memperlihatkan bahwa $\mathrm{R}^{2}=0,962$ artinya $96,2 \%, \%$ tinggi rendahnya produktivitas kerja karyawan dipengaruhi kecerdasan emosional karyawan sedangkan sisanya 3,87 . Jadi dapat disimpulkan ada pengaruh yang sangat kuat dimensi kecerdasan emosional secara serentak terhadap produktivitas kerja karyawan.

Hasil uji $F$ memperlihatkan $\mathrm{F}=535,204$ dengan taraf signifikansi sebesar 0,000 . Menggunakan standar taraf signifikansi dalam pengujian (5\%), maka hasil pengujian tersebut dapat disimpulkan "secara bersama-sama ada pengaruh yang sangat kuat dan signifikan antara kesadaran diri (X1), pengaturan diri (X2), tinggi motivasi (X3), empati (X4) dan ketrampilan sosial (X5) terhadap produktivitas kerja karyawan" Jadi hipotesis pertama dalam penelitian ini didukung oleh data empirik atau terbukti.

\section{Hasil Uji Hipotesis Pengaruh Secara Parsial}

Variabel bebas dalam penelitian ini adalah kecerdasan emosional karyawan, yang terdiri dari 5 (lima) variabel, X1, X2, X3, X4 X5. Dari uji t, notasi setiap variabel ditambah dengan notasi "Z", sehingga menjadi ZY, ZX1, ZX2, ZX3, ZX4 dan ZX5. Selanjutnya dari koefisien regresi parsial tersebut dapat dinyatakan dalam persamaan sebagai berikut:

$$
\begin{aligned}
\mathrm{ZY}= & 0,182 \mathrm{ZX} 1+0,139 \mathrm{ZX} 2+0,140 \mathrm{ZX} 3 \\
& +0,274 \mathrm{ZX} 4+0,294 \mathrm{ZX} 5 \\
& \text { Persamaan regresi linier ganda }
\end{aligned}
$$
tersebut masing-masing koefisiennya mempunyai tanda positif, artinya semakin baik kesadaran diri, semakin baik pengaturan diri, semakin tinggi motivasi, semakin bagus empati dan semakin bagus ketrampilan sosial seorang karyawan maka akan semakin tinggi pula tingkat produktivitas kerja karyawan tersebut.

Selanjutnya menguji produktivitas kerja karyawan dapat dilihat dari Tabel 8 . Hasil perhitungan yang ditampilkan dalam tabel tersebut, tampak bahwa semua variabel bebas mempunyai taraf signifikansi kurang dari 0,05 sehingga dapat disimpulkan bahwa secara parsial masing-masing variabel bebas yaitu kesadaran diri (X1), pengaturan diri (X2), motivasi (X3), empati (X4) dan ketrampilan sosial (X5) mempunyai pengaruh yang signifikan terhadap produktivitas kerja karyawan (Y). Dengan demikian hipotesis kedua yang diajukan dalam penelitian ini terbukti. 
Tabel 8: Hasil Uji Pengaruh Parsial

\begin{tabular}{|c|c|c|c|}
\hline \multirow{2}{*}{ Variabel Bebas } & Standardized Coefficients & \multirow{2}{*}{$\mathbf{t}$} & \multirow{2}{*}{ Sig } \\
\cline { 2 - 2 } & Beta & & \\
\hline X1 & .182 & 3.330 & .001 \\
\hline X2 & .139 & 4.123 & .000 \\
\hline X3 & .140 & 2.382 & .019 \\
\hline X4 & .274 & 4.421 & .000 \\
\hline X5 & .294 & 4.336 & .000 \\
\hline
\end{tabular}

Sumber: data primer diolah

\section{SIMPULAN}

Berbagai hasil dari analisis data dapat disimpulkan sebagai berikut:

1. Instrumen yang digunakan untuk menggali informasi yang berkaitan dengan dimensi dalam kecerdasan emosi dan produktivitas kerja telah dilakukan pengujiannya melalui data yang terkumpul, dan dinyatakan valid dan reliabel.

2. Dari sampel sebanyak 111 orang responden dapat diketahui bahwa pada umumnya karyawan masih mempunyai kecerdasan emosi yang rendah. meskipun pada umumnya baik, tetapi masih berada di bawah standar yang diharapkan perusahaan pada umunya.

3. Secara diskriptif rendahnya produktivitas kerja dipengaruhi oleh rendahnya tingkat kecerdasan emosi karyawan. Setelah dibuktikan dengan analisis inferensial, benar bahwa dimensi kecerdasan emosi, yang terdiri dari kesadaran diri $\left(\mathrm{X}_{1}\right)$, pengaturan diri $\left(\mathrm{X}_{2}\right)$, motivasi $\left(\mathrm{X}_{3}\right)$, empati $\left(\mathrm{X}_{4}\right)$ dan ketrampilan sosial $\left(X_{5}\right)$ secara serentak mempunyai pengaruh yang kuat dan signifikan terhadap produktivitas kerja (Y). Kesimpulan ini selaras dengan hipotesis pertama dalam penelitian ini.

4. Demikian juga, secara parsial setelah dilakukan analisis inferensial diperoleh kesimpulan bahwa semua dimensi dalam kecerdasan emosi secara parsial mempunyai pengaruh yang signifikan terhadap produktivitas kerja karyawan dan hasil inipun juga selaras dengan hipotesis kedua dalam penelitian ini.

5. Dari ke lima dimensi dalam kecerdasan emosi, yaitu kesadaran diri $\left(\mathrm{X}_{1}\right)$, pengaturan diri $\left(\mathrm{X}_{2}\right)$, motivasi $\left(\mathrm{X}_{3}\right)$, empati $\left(\mathrm{X}_{4}\right)$ dan ketrampilan sosial $\left(\mathrm{X}_{5}\right)$, yang mempunyai harga koefisien regresi parsial dari data yang telah distandardisasi, paling besar adalah ketrampilan sosial. Ini berarti dapat disimpulkan bahwa ketrampilan sosial merupakan variabel yang mempunyai pengaruh paling besar atau dominan terhadap produktivitas kerja karyawan. Ini berarti hipotesis ketiga dalam penelitian ini secara empirik terbukti.

\section{Saran}

Berdasarkan temuan-temuan dalam penelitian ini, maka saran yang dapat disampaikan kepada perusahaan adalah terus berupaya meningkatkan dan mengembangkan kecerdasan emosi pada setiap karyawan dengan beberapa cara, diantaranya adalah:

\section{Bagi pekerja}

1. Kecerdasan emosi (EQ) adalah sesuatu yang dapat dipelajari, oleh karena itu tingkatkan kemampuan refleksi (awareness) dari pengalaman hidup sehari-hari maupun yang berasal dari rekan sekerja. 
2. Lakukan pertemuan rutin berkala pada skala unit kerja atau tim kerja yang lebih kecil untuk berbagai pengalaman melalui 3 (tiga) person EQ Teaching, yaitu: "Saling menceritakan pengalaman dalam kaitannya dengan EQ, saling melakukan analisis, dan ambil kesimpulan.

3. Menghindari dari penyakit toxic employee yang membuat semangat dan energi di tempat kerja menurun. Ciriciri toxic employee diantara-nya adalah: "Pikiran negatif (negative thinking) dan pesimis, menjadi sumber masalah (trouble maker) bagi tim kerja, tidak pernah dapat memberi solusi, kesadaran akan kualitas kerja sangat rendah, emosional dikedepankan dari pada rasionalitasnya, penyebar gosip yang belum tentu benar, dan tidak pernah mensyukuri apa yang telah didapat, tetapi selalu menuntut.

4. Selain mengembangkan kemampuan teknis, diharapkan juga belajar mengembangkan life skills lainnya, dengan melalui berbagai bacaan, seminar atau audiovisual.

\section{Bagi manajemen}

1. Segera melakukan sosialisasi atau lebih membumikan pentingnya kecerdasan emosional dari sekedar merka mempunyai IQ yang tinggi, karena hal ini akan dapat memberikan berbagai benefit bagi perusahaan.

2. Membentuk suatu tim khusus untuk mengkaji dan mempelajari lebih mendalam mengenai EQ, kemudian melakukan pengembangan internal dan sekaligus sebagai tempat konseling bagi karyawan.

\section{DAFTAR PUSTAKA}

Agustian, Ary, Ginanjar. (2005). Rahasia Sukses Membangkitkan ESQ Power, Jakarta: Arga.

Anthony Dio Martin. (2006). Smart Emotion (Membangun Kecerdasan Emosi), Vol.1 Jakarta, PT. Gramedia Pustaka Utama.
3. Perusahaan sebaiknya juga bertindak sebagai fasilitator dan pendamping karyawan dalam melakukan pekerjaan, bukan hanya memerintah, tetapi juga mendengarkan, menyediakan dan melayani, sehingga karyawan akan dapat bekerja dengan penuh ketenangan dan kedamaian.

4. Mengurangi campur tangan Manajer dalam hal-hal yang kecil dalam suatu pekerjaan, karena hal itu dapat membuat karyawan frustasi. Jika hal ini dilakukan, maka akan dapat meningkatkan rasa tanggung jawab, fleksibilitas dan memperlancar inovasi yang berarti meningkatkan produktifitas kerja.

5. Kembangkan ketrampilan sosial karyawan dengan membina sambung rasa, untuk menghilangkan isolasi dalam lingkungan kerja. Hubungan pribadi dapat merupakan perekat alami yang memungkinkan sebuah tim kerja memiliki tingkat produktivitas tinggi.

\section{Bagi Manajemen SDM Global}

Persaingan di pasar tenaga kerja sangat luar biasa ketatnya, sementara lembaga pemberi kerja sangat terbatas jumlahnya. Oleh karena itu untuk menjadi sumber daya manusia yang berkualitas diperlukan:

1. Kesadaran akan pentingnya EQ dibanding IQ.

2. Kecerdasan untuk menangkap peluang, sehingga meningkatkan nilai tambah pada diri sendiri.

3. Jangan pernah berhenti untuk berinovasi, karena perjuangan untuk hidup semakin keras, dan tidak dapat diatasi hanya dengan tindakan yang emosional. 
SIIERGI Vol. 9 No. 2, JUNI 2007: 179 - 192

Cooper, Robert K., dan Ayman Sawaf. (2002). Executive EQ, Kecerdasan Emosional Dalam Kepemimpinan dan Organisasi, Edisi bahasa Indonesia, Jakarta: PT. Gramedia Pustaka Utama.

Direktur Utama PT. Pertamina. (2002). Pedoman Kompetensi Jabatan Pertamina, Jakarta: PT. Pertamina.

Divisi SDM dan Direktorat Umum dan SDM. (2005). Pedoman Pengelolaan SDM, Jakarta: PT. Pertamina (Persero).

Goleman Daniel, Richard B, Annie M. (2004). Kepeminpinan Berdasarkan Kecerdasan Emosi, Jakarta: PT. Gramedia Pustaka Utama. , Emotional Intellegence. (2005). Jakarta: PT. SUN, Cetakan ke 15

Ketua Dewan Direksi. (2005). Pedoman Pengelolaan SDM, Jakarta: Divisi SDM Direktorat Umum Dan SDM.

PT. Pertamian (Persero) Unit Pengolahan VI Balongan, Menuju Kilang Unggulan, 1997, Humas Kilang UP-VI Balongan.

Schuler, Randall S., Susan E.Jackson. (1996). Manajemen Sumber Daya Manusia, Menghadapi Abad ke-21, Edisi Keenam, Jilid 1, Alih Bahasa Dwi Kartini Yahya, Jakarta: Erlangga.

Sekaran, Uma. (2003). Research Methods for Business, A Skill-Building Approach, Fourth Edition, New York: John Wiley \& Sons, Inc.

Simamora, Henry. (1999). Manajemen Sumber Daya Manusia, Edisi Kedua, Yogyakarta: Bagian Penerbitan STIE YKPN.

Spencer Johnson, M.D. (2001). Who Moved My Cheese, Jakarta: Penerbit PT.Elex Media Komputindo Kelompok Gramedia.

, M.D. (2001). The One-Minute Manager, Jakarta: Penerbit PT. Elex Media Komputindo Kelompok Gramedia.

Usmara, A. (Ed). (2002). Paradigma Baru Manajemen Sumber Daya Manusia, Edisi ke 2, Yogyakarta: Amara Books 